10.17805/zpu.2016.4.5

\title{
Современный российский капитализм: социологический, политико-экономический и антропологический аспекты *
}

\author{
Г. Ю. КАНАРШ \\ (ИНСТИТУТ ФИЛОСОФИИ РОССИЙСКОЙ АКАДЕМИИ НАУК)
}

В статье предпринята попытка комплексного социально-философского анализа феномена современного российского капитализма. Автор предлагает рассмотреть современный российский капитализм с трех взаимосвязанных точек зрения - социологической, политико-экономической и антропологической. Подчеркивается связь российского капитализма с глобализацией, порождаемыми ею вызовами.

Как показано в статье, с социологической точки зрения российский капитализм представляет собой клановую систему, отношения в которой строятся не на основе конкуренции (как в «нормальной» капиталистической системе), а на основе личных (неформальных) отношений. В свою очередь, клановая система есть лишь форма, в которой осуществляется хозяйственная деятельность. Непосредственная причина формирования клановости - феномен власти-собственности, чьи проявления можно наблюдать и в современной России. В то же время безраздельное господство в современном российском обществе государственной бюрократии и слабость правовых начал объясняются автором не только с исторической точки зрения, но и с точки зрения характерологической. Предполагается, что важнейшая причина этого - слабость замкнуто-углубленного (аутистического) характерологического радикала (типа характера) в национальном характере россиян. Напротив, народы стран Восточной и Юго-Восточной Азии, демонстрирующие поистине феноменальные успехи капиталистического развития (примерно с 1960-х гг.) отличаются как раз выраженностью данного характерологического радикала в национальном характере. Результатом этого становится прагматизм, обнаруживающий себя во всех слагаемых азиатского «экономического чуда» - от четкого следования правилам общественной и экономической жизни до кропотливого повседневного труда.

Ключевые слова: российское общество, капитализм, клановость, власть-собственность, национальный менталитет, национальный характер, новые индустриальные страны, «азиатское чудо», модернизация.

\section{ВВЕАЕНИЕ}

$\mathrm{K}^{\mathrm{s}}$ ак известно, одним из главных вызовов, стоящих перед современными народами и государствами, является глобализация - процесс, определяющийся победой транснационального капитала и информации над национальными интересами (Федотова В., Федотова Н., 2002: 5). Глобализация означает, что сегодня поведение капитала определяется только одним - он уходит туда, где ему выгодно. Аля того, чтобы быть успешной на глобальном рынке (и в частности, быть привлекательной для инвесторов) национальная экономика должна предложить миру что-то такое, чего не может предложить другая страна, - уникальный товар или как альтернатива - товар, производящийся другими странами, но значительно более дешевый. Большое значение имеет и бренд, под маркой которого данный товар производится (и который сам по себе может придать товару характер уникальности). «Уни-

* Статья подготовлена в рамках поддержанного РГНФ научного проекта «Социально-философский анализ современного российского капитализма» (грант №15-03-00580).

The article has been prepared within the framework of the research project "Capitalism in contemporary Russia: a social and philosophical analysis" supported by the Russian Foundation for the Humanities (Grant No. 15-03-00580) 
кальность и дешевизна - два важнейших фактора вхождения в глобальную экономику» (там же: 7). Отвечая на вопрос о том, как десять незападных стран (Бразилия, Индия, ЮАР, Турция, Польша, Южная Корея, Китай, Аргентина, Мексика, Индонезия) вошли в глобальную экономику, В. Г. Федотова отмечает следующее: «...они смогли это сделать, т. к. стали производить тот или иной продукт, который оказался или самым лучшим, или самым дешевым из этого класса товаров для мирового рынка, а также был информационно представлен людям в качестве такового» (там же: 7).

Здесь характерен пример Китая, на протяжении более чем двух десятилетий производящего достаточно качественную промышленную продукцию для рынков западных стран, но значительно более дешевую, что и предопределило в значительной мере возможность вхождения этой страны в глобальную экономику. То же самое касается таких стран, как Турция, Индия, Польша и др. Такая ситуация заставляет задаться вопросом: какой должна быть современная российская экономика для того, чтобы Россия стала не только частью глобального мира (каковой она, безусловно, является), но и частью глобальной экономической системьи?

В свою очередь, поставленный выше вопрос может показаться риторическим: Россия должна стать страной, производящей не только сырье и поставляющей это сырье на рынки Запада и Востока, но и одной из развитых современных промышленных держав. Известно, что Советский Союз как раз и был одной из таких держав и что после распада СССР этот статус был в значительной мере утрачен. Однако какая связь существует между сырьевым характером российской экономики и ее положением в системе мирового хозяйства? Безусловно, такая связь есть, и раскрывается она, как известно, через понятие периферийного капитализма. Среди исследователей, разделяющих положения миросистемного анализа, трактующего Запад как центр мировой капиталистической системы, а весь остальной мир как его периферию, Россия однозначно относится к числу стран, экономика, политика и общество которых характеризуются чертами, типичными для стран капиталистической периферии. А именно, как мы уже сказали, сырьевой и әкспортоориентированный характер экономики, наличие крайних диспропорций и большого социального неравенства в рамках существующей социально-экономической системы, а также - авторитарного режима, который является необходимым условием существования таких экономики и общества, обеспечивая господствующим группам те условия, при которых они имеют возможность сохранить свое господство. Именно такой общественно-экономический строй, даже признавая факт определенной его эволюции за последние 25 лет, сложился в России (Кагарлицкий, 2009: 518-569).

В связи с этим возникают три группы вопросов. Во-первых, что представляет собой современный российский капитализм, каковы его происхождение и природа? Вовторых, есть ли отличия российского «периферийного капитализма» от того типа капитализма, который сложился на, казалось бы, еще более глубокой периферии в странах Восточной и Юго-Восточной Азии, и которые, несмотря на свою «периферийность» показывают поистине феноменальные экономические успехи? И, в-третьих, каковы пути возможной трансформации российской экономики, которые сделали бы реальными столь же яркие экономические успехи России в условиях глобальной экономической конкуренции? Все эти вопросы заставляют более пристально присмотреться к «лицу» современного российского капитализма, одновременно сравнивая сложившийся в России социально-экономический строй в других незападных стра- 
нах, что, на наш взгляд, позволит более глубоко понять его особенности, тесно, как показывает практика, связанные с особенностями национального характера и менталитета России.

\section{СОВРЕМЕННЫЙ РОССИЙСКИЙ КАПИТААИЗМ: ОСНОВНЫЕ ХАРАКТЕРИСТИКИ}

Главная проблема, которая возникает в связи с анализом российского капитализма, - это проблема развития (модернизации). Как мы уже сказали выше, войти в глобальную экономику возможно только производя что-то уникальное, либо самое дешевое из того же класса товаров. Именно данной потребностью - вхождения в глобальную экономическую систему - объясняется сегодняшний спрос на инновации, в том числе, в российском обществе. Однако проблема заключается в том, что экономическая система, созданная в России, признается большинством исследователей принципиально неинновационной. Российский бизнес, от которого ожидается инновационное поведение, ведет себя принципиально иным образом, предпочитая долгосрочным вложениям (инвестициям) стратегии, направленные на получение быстрой прибыли. Чем объяснить подобное поведение российского бизнессообщества?

Таких объяснений существует два. Первое связано с особенностями той общественно-экономической системы, которая сложилась в России в последние два с половиной десятилетия. Второе - с особенностями сырьевой экономики, которая, в свою очередь, «выстраивает» под себя общественную и политическую систему. Оба эти аспекта, в конечном счете, представляют собой два разных аспекта системы, которая была выше охарактеризована нами как система периферийного капитализма.

Итак, общественно-экономическая система современной России, ее основные характеристики. По мнению ряда исследователей, сущностной чертой этой системы является клановый характер отношений между субъектами экономической деятельности. В противоположность «нормальному» капитализму, в котором экономические отношения - это отношения между частными собственниками, основанные на конкуренции, российский капитализм - это клановая система, в которой права собственности являются вторичными, так же как и конкуренция, а главным является принадлежность того или иного субъекта к определенному клану (неформальной группе), что позволяет выстраивать неформальные отношения как внутри своей группы, так и за ее пределами (с другими подобными группами), осуществляя на основе неформальных договоренностей контроль над собственностью и получаемыми от нее доходами. Все это позволяет исследователям характеризовать российский капитализм как «клановый», «семейно-клановый»и т. п., а также отмечать значительное сходство между социально-экономической системой современной России и феодальными отношениями. Как отмечает, например, социолог $\Lambda$. Я. Косалс, «...пецифика российского капитализма, его отличие от “классического” капитализма свободной конкуренции, каким он сегодня сформировался в Европе и Северной Америке, в том, что его главные действующие лица - социально-экономические кланы, а не частные предприниматели, более или менее свободно конкурирующие между собой. Поэтому предлагаю возникшую в России систему называть клановым капитализмом» (Косалс, 2011: 417-418).

Что характеризует клановую систему? Прежде всего, как мы уже сказали, наличие кланов, или неформальных групп, в рамках которых осуществляются договоренности 
между хозяйствующими субъектами. Кланы имеют достаточно сложную структуру, которая включает в себя лидера, или вождя клана, его ближайшее окружение, или команду, а также внешних «агентов влияния» (там же: 420-421). Таким образом, первая важнейшая черта клановой системы - это разделение экономических субъектов на «cboux» $u$ «иужих», при этом по отношению к «своим» демонстрируется лояльность, в то время как поведение по отношению к «чужим» характеризует оппортунизм, т. е. стремление действовать в интересах своего клана. Такое поведение, существенно ограничивающее радиус доверия, само по себе крайне отрицательно сказывается на экономической деятельности (Розмаинский, Аожникова, 2014: 44). Вторая важнейшая черта клановой системы - неформальный характер отношений между кланами (как и внутри одного клана). Если в нормальной рыночной экономике отношения между субъектами выстраиваются на основе формальных контрактов, защищаемых государством, то отношения между кланами строятся, как мы уже сказали, на основе неформальных договоренностей. При этом важнейшим условием возможности такого рода договоренностей выступает так называемая система конъертачии ресурсов, действующая в рамках специфических закрытых дисфункциональных рынков (Косалс, 2011: 423-424). Проще говоря, ресурсы, имеющиеся в распоряжении кланов - экономические, административно-политические, силовые, - постоянно обмениваются друг на друга в рамках неформальной, теневой экономики. Таким образом, клановая система способствует расширению теневого сектора, т. е. нелегальных и полулегальных форм предпринимательства, что, естественно, повышает риски и в целом не является благоприятной средой для инвестиционной активности. Еще одна важнейшая черта клановой системы, препятствующая формированию нормального делового климата, - создаваемый ею монополизм. Речь идет о том, что, как правило, чиновники, являющиеся членами того или иного клана и «кормящиеся» от доходов этой группы, склонны создавать для «своих» режим наибольшего благоприятствования на рынке, тогда как «чужие» (представители иных, часто враждебных, кланов или независимые предприниматели) «выдавливаются» с рынка. В целом «все это означает, что получает распространение ориентация на быструю окупаемость проектов» (Розмаинский, Аожникова, 2014: 44). Нужно сказать, что клановость в России - черта не только әкономической системы, - она пронизывает общественные отношения снизу доверху, включая в себя кланы «федерального значения», региональные кланы, а также криминальные группировки. При этом число кланов на каждом уровне подчас измеряется тысячами (Косалс, 2011: 432-437).

Важный вопрос, который возникает в связи с этим: какая ситуация способствует возникновению клановой системы? Почему в постсоветской России вместо нормального капитализма как общественной системы сформировалось нечто принципиально иное, живущее не по законам рынка, а по законам клановых, полуфеодальных отношений?

Как отмечает упомянутый выше $\Lambda$. Я. Косалс, кланы начали складываться уже в рамках советской системы - прежде всего, в рамках таких, получивших известность феноменов, как ведомственность и местничество. Известно, что на поздних этапах существования советского общества (1970-1980-е гг.) значительное влияние в рамках системы получили разного рода обособленные структуры - различные ведомства (например, союзные и республиканские министерства), а также бюрократия на местах. Эти явления стали возникать уже во времена нахождения у власти Н. С. Хрущева, но особенно заметными они стали в «эпоху застоя». Фактически на поздних эта- 
пах существования СССР речь может идти о подмене общегосударственного интереса различными частными интересами - сгруппированными вокруг министерств, ведомств, отдельных предприятий. Эта ситуация усугубилась на закате советской системы - в период перестройки, когда советская номенклатура, предвидя грядущий распад системы, занялась приватизацией государственной собственности. В итоге период номенклатурной приватизации «приватизации государства государством»это время, когда начинают складываться «ядра» будущих кланов, которые позже в период 1990-х годов станут основными «игроками» в рамках новой российской общественно-экономической системы (Косалс, 2011: 438-439).

Однако главная причина формирования клановой системы заключается не просто в «наследии» номенклатурного прошлого. Эта причина состоит в другом - а именно в той крайне враждебной, по сути, анархической социальной среде, в которой начинает складываться будущее российское предпринимательство. Не случайно поэтому «вхождение в закрытое неформальное деловое сообщество обеспечивало лучшую защиту бизнеса и жизни, чем положение "волка-одиночки", вынужденного опираться только на свои силы и защиту государства, у которого были совершенно другие заботы. Кроме того, в рамках таких сообеств обеспечивался высокий уровень доверия в деловых отношениях, что было особенно важно в начальных условиях трансформации и отсутствия многих формальных институтов» (там же: 441).

Таким образом, клановая система - вполне естественное образование в условиях слабости государства и неразвитости правовых отношений. Задача кланов - в снижении риска и неопределенности для своих членов в условиях, когда формальные институты слабы или совсем не работают, хотя при этом возникающая система сама по себе является неэффективной и провоцирует значительное количество рисков (например, риск очередного передела собственности в рамках «клановых войн») (см., напр.: Аамажаа, 2010). И самое главное - такая система, как мы уже сказали, предопределяет краткосрочную ориентацию бизнес-сообщестьа, «перекрывая» поток инвестиций и тормозя развитие как экономики, так и общества.

Зададимся вопросом: насколько данная система характерна для современной экономической ситуации в России, или она является исключительно «достоянием» 1990-х годов, с характерной для них системой олигархического капитализма?

С одной стороны, нельзя отрицать того факта, что ситуация в экономике и обществе (как и в политике) существенно изменилась после прихода к власти В. В. Путина. Мы имеем в виду как уже отмеченное усиление государства в экономике, изначально провозглашенную новым президентом политику «равноудаленности»в отношении олигархов, так и довольно значительные перемены в самой экономике (относительный подъем производства) и в целом - увеличение благосостояния людей. Что касается олигархических кланов, окончательно сформировавшихся с середины 1990-х годов, то здесь произошла не столько ликвидация их государством, сколько подчинение их единым «правилам игры». «Жесткие дисциплинарные меры Путина превращали сборище грабительских кланов в некое подобие респектабельного буржуазного класса» (Кагарлицкий, 2009: 553). При этом необходимо отметить, что подобное дисциплинирование со стороны власти было жизненно важно и для самих олигархов, поскольку давало гарантии их собственному существованию, которое становилось невозможным в условиях продолжающегося распада страны. С другой стороны, после прихода Путина к власти система изменилась скорее количественно, но не качественно. Безусловно, она прошла определенную эволюцию, начиная 
с 1990-х годов, однако особенность нынешнего периода состоит скорее в том, что вместо борьбы множества кланов между собой доминирующее положение в системе занял один клан ( «новосемейный», «новопитерский»). Как считает $\Lambda$. Я. Косалс, именно в этот период в стране появились настоящие олигархи, поскольку государственная бюрократия вновь начала обмен власти на собственность. «На практике это был захват высших постов в этих компаниях (бывших владениях олигархов. - Г. К.) представителями “верховного клана”. ...В результате “верховный клан” взял под контроль большинство сверхкрупных предприятий-монополистов, производящих значительную часть ВВП. Те, кто контролирует эти государственно-частные структуры, являются настоящими олигархами» (Косалс, 2011: 444). Поэтому можно согласиться с теми исследователями, которые разделяют «семейно-клановый» капитализм в России на два вида: «олигархический», соответствующий 1990-м годам, и «бюрократический», соответствующий периоду с начала 2000-х годов (Розмаинский, Аожникова, 2014: 43).

Примерно те же выводы можно сделать и в отношении нового способа организации экономической системы современной России, а именно - осуществившегося со второй половины 2000-х годов перехода от чисто олигархической системы к системе государственных корпораций. В стране был создан целый ряд крупных государственных объединений, возникших для решения тех или иных задач, имеющих приоритетное государственное значение (корпорации «Роснано», «Ростех», «Росатом» и др.). «Госкорпорации получили сверхпривилегированные условия функционирования, особый правовой статус, широкий набор полномочий, значительные объемы государственного имущества и средств бюджета. Их создание преподносилось как панацея от всевозможных бед российской экономики» (Соколов, 2013: 83). При этом официальные причины образования госкорпораций носили вполне рациональный характер: утверждалось, что конкурировать на мировом рынке сегодня могут только подобные индустриально-технологические гиганты, с концентрированными в них огромными средствами, а не отдельные предприятия. Не случайно поэтому российские госкорпорации сравниваются некоторыми исследователями с южнокорейскими «чеболями» или японскими «дзайбацу». По этой же причине капитализм в России начала третьего тысячелетия нередко определяется как «государственный капитализм», и опять же в сравнении с аналогичной моделью в странах Восточной и Юго-Восточной Азии. ОАнако правомерен вопрос: насколько существующая модель действительно соответствует понятию «государственного капитализма», а созданные госкорпорации отвечают своему назначению? Как показывают некоторые исследования, подлинная ситуация вокруг этих мощных объединений далека от изначально заявленных целей. Государственные корпорации в России, так же как и остальной бизнес, действуют не в логике развития (модернизации) экономики, а в логике получения быстрых доходов, причем с использованием полукриминальных методов. Как отмечает, в частности, экономист Р. С. Азарасов, «госкорпорации характеризуются их изъятием из установившегося порядка контроля за хозяйствующими субъектами со стороны правоохранительных органов, непрозрачностью их финансовых потоков, сетью аффилированных структур и непомерно раздутыми издержками производства» (Азарасов, 2012: Электронный ресурс). Такая ситуация - фактическое отсутствие контроля со стороны общества и государства - делает госкорпорации и аккумулированные в них огромные финансовые ресурсы «лакомым куском» для тех же неформальных, клановых групп, борьба между которыми по-прежнему определяет облик общественно-экономической системы современной России. 
Таким образом, можно говорить о том, что нынешняя российская общественноэкономическая система, хотя и отличается в значительной мере от системы периода 1990-х годов, тем не менее сохраняет в полной мере свою «семейно-клановую» природу, т. е. она не изменилась по существу. Значительно выросшая с начала 2000-х годов роль государства в экономике вовсе не отменяет того факта, что за государственными структурами по-прежнему скрываются интересы отдельных кланов, борющихся между собой за влияние и перераспределение собственности. Это, в свою очередь, заставляет предположить, что такая относительная неизменность природы российского капитализма обусловлена причинами более глубокими, нежели только особенности трансформационной экономики. Полагаем, что эти причины носят не столько социально-экономический, сколько социокультурный характер, а лучшему, более наглядному выявлению этих причин будет способствовать сравнительный анализ особенностей российской экономики и экономики других стран, вставших на путь капиталистического развития - прежде всего демонстрирующих феноменальный успех стран региона Восточной и Юго-Восточной Азии.

\section{КАПИТААИЗМ В РОССИИ И В СТРАНАХ КОНФУЦИАНСКОГО РЕГИОНА: СРАВНИТЕАЬНАЯ ХАРАКТЕРИСТИКА}

Подчеркнем еще раз, что главная проблема современного российского капитализма - его рентоориентированный характер, направленность на скорое извлечение дохода, а не на долгосрочные вложения (инвестиции), как это происходит в условиях «нормальной» рыночной экономики. Причем, что важно, такая ориентированность характерна не только для бизнеса, призванного осуществлять инновации, но и для представителей государства, патронирующих бизнес, что является нормальным в российских условиях. Не случайно поэтому российская власть обозначается в некоторых работах как «власть-временщик», видящая свою задачу не в модернизации экономики и общества, но исключительно в собственном быстром обогащении (Глебова, 2006: 90-97).

В значительной мере, как мы показали выше, такая ориентированность и бизнеса, и чиновников предопределяется клановой системой, с ее эффектами (разделение на «своих» и «чужих», монополизация экономики, расширение сферы теневой экономики). Однако существенно, что клановость в российских условиях выступает только формой, в рамках которой осуществляется хозяйственная деятельность. Более фундаментальной чертой являются особенности политической (политико-экономической) системы, тесно связанные, в свою очередь, с особенностями национальной ментальности.

Здесь на первый план выходит такое ключевое для России явление, как Власть-собственность.

Формирование системы власти-собственности в России, как правило, объясняется исторически, в связи с особенностями складывания Московского государства (Московской Руси) в XV-XVI вв. Здесь ключевым моментом является учреждение в Московском царстве поместной системь, что, в свою очередь, было новацией, позаимствованной московскими государями у Османской империи (Нуреев, Аатов, 2011). Введение поместной системы означало, что вся собственность в государстве начинает рассматриваться как служебная, т. е. наделение ею осуществляется не на основе происхождения (знатности), а на основе государевой службы. Как известно, реформы Ивана III, а затем Ивана IV (Грозного) были направлены на искоренение форм влас- 
ти и собственности, независимых от верховной власти, и введения поместной системы в качестве общего правила. Считается, что, несмотря на изменение образцов для подражания (в XVII в. на место Османской империи пришел Запад), система «власти-собственности» прочно укоренилась в общественно-политическом строе Российского государства и отчетливо проявляла себя как во время первого российского капитализма (вторая половина XIX - начало XX в.), так и во время Советского социалистического государства.

Если говорить о нынешнем периоде развития России, то феномен власти-собственности вновь со всей очевидностью обнаруживает себя. Как пишет, например, известный экономист и политик Г. А. Явлинский, «...трудно не заметить, что политически страна за пятнадцать постсоветских лет (написано в середине 2000 -х годов - Г. К.) совершила не всегда заметный для внешнего наблюдателя маневр, вернувшись к модели, от которой вполне добровольно отошла в феврале 1917 г. ...В целом политическое устройство “посткоммунистической” России в итоге воспроизвело режим позднего самодержавия почти со всеми присущими ему историческими особенностями и отношениями» (Явлинский, 2007: 17-18). При этом существенно, что российский менталитет выявляет себя и в том, что склонность русских к самодержавному правлению сочетается в России со слабостью формальных (правовых) начал, что фактически означает безраздельное господство бюрократии, которая становится, наряду с самодержцем, единственным «хозяином земли русской». В этих условиях вполне естественным является возрождение традиционной для России системы власти-собственности, когда экономические активы, даже находясь формально в частном владении, тем не менее рассматриваются конкретным чиновником как собственность государства. «Это - система, в которой право частной собственности существует в очень ограниченном и ущербном виде. Хотя формально не существует (или почти не существует) ограничений на размер и характер активов, которые могут находиться в частной собственности, фактически персонифицированная собственность на все сколько-нибудь крупные активы является условной, так как может быть в любой момент изъята волевым решением власти без полноценной компенсации. ...А это означает, что собственником всех значимых экономических активов в обществе является государство, которое, однако, допускает к распоряжению ими частные лица и организации на условиях им, то есть самим государством, и определяемых» (Явлинский, 2007: 26-27; курсив наш. $-\Gamma . K$.$) .$

В свою очередь, это означает возникновение системного дефицита доверия, когда бизнес оказывается не готовым к реализации сколько-нибудь долгосрочных инвестиционных проектов из-за того, что никто в таком обществе не может гарантировать ему стабильность и безопасность его положения. В целом же такая ситуация означает возникновение специфической системы общественного воспроизводства, для которой характерно не создание материальных благ (как при «нормальном» капитализме), а постоянное перераспределение собственности. Естественно, что в рамках такой системы вести нормальный бизнес становится невозможным, поэтому единственным выходом для предпринимателя становится выстраивание неформальных (клановых) отношений с государственной бюрократией, либо продажа активов и полное оставление бизнеса. В экономическом же плане наиболее рациональной стратегией представляется не столько развитие бизнеса, сколько извлечение ренть, т. е. быстрого и, как правило, незаработанного дохода, во многом за счет неиспользования возможностей капитальных вложений. 
Принципиально иную ситуацию мы можем наблюдать в новых индустриальных странах Восточной и Юго-Восточной Азии (Китай и «тигры»). Главное отличие экономик стран этого региона от российской экономики состоит в том, что здесь господствует не идея постоянного «передела», а идея производства, что связано как с определенными институциональными условиями, так и с особенностями национального характера и менталитета. Каковы же основные предпосылки феноменального экономического успеха этих стран?

Итак, первое важнейшее условие успешного экономического развития стран этого региона - наличие твердого правового порядка, учреждаемого и поддерживаемого властью. Безусловно, страны этого региона имеют определенное сходство с Россией в плане устройства своих государств и обществ - оно заключается прежде всего в наличии авторитарной власти в политике и клановой системы в обществе. Однако вместе с тем восточно- и юго-азиатские социумы сделали ставку на развитие формальных (правовых) начал как необходимого условия развития капитализма. Поэтому можно согласиться с автором, показывающим связь успешного капитализма в «капиталистическом» Сингапуре и «коммунистическом» Китае с культивированием в этих странах жесткой общественной дисциплины и законности, в том, что «стратегической альтернативы системе институтов, называемых иногда «западными», не существует» (Илхарионов, 2007: Электронный ресурс).

Вторая важнейшая черта - наличие так называемого государства развития, т. е. политических режимов, нацеленных на осуществление модернизации. При этом важно отметить, что такая нацеленность является не только характеристикой элит, но и особенностью сознания масс, что обеспечивает необходимый национальный консенсус. «Один из признаков такого (“правильного”) авторитаризма, который совершенно не просматривается в сегодняшней России, - мобилизационный настрой общества на модернизацию, присущий и элитам, и низам. И те, и другие были готовы жертвовать сиюминутной выгодой ради достижения стратегических успехов, тогда как в России правящие круги отнюдь не собираются затягивать пояса ради инвестиций в новые отрасли промышленности или народное образование» (Красильщиков, 2003: 10). Справедливости ради нужно отметить, что на определенном историческом этапе и в России (СССР) существовал широкий общественный консенсус в отношении модернизации - это верно прежде всего по отношению к сталинской программе развития. Однако, как показывает, в частности, политолог О. В. Гаман-Голутвина, в конечном счете общество устало от модернизационных усилий, что подкреплялось сравнительно неплохим уровнем жизни в позднем СССР, а главное - стремлением позднесоветской номенклатуры окончательно решить проблему владения огромной государственной собственностью в свою пользу. В результате и общество, и власть отказались от идеи развития в пользу сытой и обеспеченной жизни «как на Западе» (Гаман-Голутвина, 2010: 77-84). Между тем, если говорить о новых индустриальных странах, то в них переход к осуществлению модернизации начинался с «низкого старта», т. е. с условий жизни, которые трудно назвать нормальными. Так, 1950-е 1960-е годы, время первой волны модернизации в этом регионе, характеризовались крайне низким уровнем и качеством жизни, хроническим недоеданием и даже голодом. Поэтому во многом понятен настрой новых индустриальных стран, а также сегодняшнего Китая на реализацию идеи развития.

Третья черта - осуществление в этих странах, наряду с политикой промышленного развития, реформ в сельском хозяйстве, которые были необходимы для того, что- 
бы накормить огромное население. Эти реформы проводились одновременно с созданием современной промышленности и рассматривались как важная часть политики преобразований.

Четвертая черта - готовность этих обществ к культурным самоизменениям. Здесь ситуация не одинакова для разных слоев обществ этого региона. Наиболее готовым к модернизации оказались этнические китайщы (в том числе китайские диаспоры тех стран, где китайцы не являются титульным әтносом). Напротив, представители иных этносов (например, малайцы) были значительно менее восприимчивы к особенностям рыночной экономики. Именно поэтому в некоторых из этих стран (например, Малайзии) властям пришлось осуществлять политику рекультуризации, в том числе, внеэкономическими методами - например, создавая административным путем особые привилегированные возможности для ведения бизнеса для титульных этносов. Напротив, этнически китайское население изначально оказалось вполне готовым $\kappa$ реализачии задач развития и к освоению рыночных ценностей, в том числе в значительной мере из-за специфического «рыночного» менталитета китайцев (Антипин, 2014).

Пятая черта - активная сочиальная политика, направленная на искоренение бедности и преодоление неравенства. С одной стороны, такая политика была связана с пониманием элит государств «авторитаризма развития» того, что рост социального неравенства в условиях капитализма может способствовать росту протестных настроений; поэтому изначально делалась ставка на его искоренение; с другой стороны, здесь оказываются важными и начионально-ментальные особенности, в соответствии с которыми и представители әлит, и выходцы из низов осознавали себя сидящими «в одной лодке», а следовательно, понимание того, что рост уровня жизни одних не должен сопровождаться падением уровня жизни других. Именно поэтому даже в современном Китае, характеризующемся достаточно высоким уровнем социального неравенства, рост уровня жизни, например, в среднем классе, одновременно сопровождается повышением уровня жизни крестьянского населения, что, в свою очередь, объясняется не только высокими темпами роста ВВП, но и существующей политикой распределения доходов (Ааньков, 2010: Электронный ресурс). Впечатляющим в этом смысле является пример авторитарного развития Южной Кореи в 1960-х - 1980-х годах, где заработная плата учителя средней школы была приравнена к заработной плате армейского офицера (в звании капитана армии), что говорит, в том числе, и об особенном отношении руководства этих стран к системе образования. Ничего подобного мы не можем наблюдать в современной России - внимательной к развитию науки и образования, опять же, российская (советская) власть была только в эпоху социалистической модернизации.

И, наконец, еще одна черта - это постепенный характер преобразований в странах этого региона. Речь идет о том, что в отличие от «революционного» метода преобразований, весьма характерного для России, руководство стран Восточной и ЮгоВосточной Азии придерживается иного подхода - nостепенных, пошаговьх преобразований, когда реформы начинаются в одной сфере (например, в сельском хозяйстве, или в легкой промышленности), и далее продвигаются в направлении более сложных сфер народного хозяйства - например, развития наукоемкой промышленности, создания собственного машиностроения, систем безопасности и производства современной электронной техники. В этом отношении весьма показательными являются реформы Аэн Сяопина в Китае, которые осуществлялись как последовательная 
реализация не одной, а четьцех модернизачий (начиная с сельского хозяйства, и заканчивая созданием современного ракетостроения и электроники). При этом надо отметить, что такой ход реформ также в немалой степени связан с особенностями менталитета китайцев, который «...предполагает последовательность и системность в действиях, отсутствие спешки или, говоря бытовым языком, суеты в осуществлении преобразований. Поэтому, какой бы аспект китайских реформ ни рассматривать, мы все равно придем к тому, что главное тут - здравый смысл» (Аенисов, 2011: Электронный ресурс).

Мы бы сказали немного иначе - не просто здравый смысл, но прагматизм китайцев, сказавшийся, в частности, в их умении воспользоваться благоприятной внешнеэкономической конъюнктурой для развития своих обществ. Так, внешнеэкономической основой развития первых новых индустриальных стран Азии стало их использование, с одной стороны, перехода западных стран на рельсы постиндустриального развития, а с другой стороны, использование стремления западных стран (прежде всего США) к противостоянию с СССР, что, в свою очередь, означало готовность Запада инвестировать в экономики восточно-азиатских государств, а главное - открыть для их продукции свои рынки. В то же время прагматизм выразился и в активном освоении экономиками этих стран преимуществ глобализачии, которые заключаются в возможности свободного перетока капиталов, технологий и информации из одних стран и регионов в другие, в зависимости от экономической конъюнктуры. Здесь можно отметить как налаживание экономических отношений с Западом, так и между собой - что выразилось в реализации спещифической стратегии «летяшие гуси», когда есть одна страна-лидер (ею до сих пор является Япония), которая через размещение своих капиталов и привнесение технологий постепенно «подтягивает» другие страны региона до своего уровня, передавая им производство менее сложной продукции. Поэтому прав автор, полагающий, что опыт Восточной и Юго-Восточной Азии для России «...является поистине бесценным. Он учит, как можно и нужно использовать себе во благо тенденции, разворачивающиеся в мировой экономике» (Красильщиков, 2003: 17).

Но главное, конечно, это труд, трудовые усилия населения этого региона, готовность огромных масс людей работать при удлиненной продолжительности рабочего дня и рабочей недели за сравнительно скромное вознаграждение. "Аействительно, за азиатским “чудом" стояла каждодневная, кропотливая работа, которую делали от зари до зари миллионы людей, будь то девушки-работницы на сборочных линиях или высшие менеджеры филиалов крупнейших фирм мира. Это “чудо" представляло собой последовательное, хотя и очень быстрое восхождение по ступенькам прогресса экономического, социального, технологического» (там же: 19).

Аумается, что все основные составляющие «азиатского чуда» являются взаимосвязанными - начиная от создания основ правового государства до упорного производительного труда. И природной, характерологической основой, на которой выстраивается здание модернизации конфуцианского региона, выступает особый вариант замкнуто-углубленного (аутистического) характера (Бурно, 2016а: Электронный ресурс; Бурно, 2008: 43-57; Волков, 2013: 276-324). Своеобразие этого характера - в сравнении с другими характерологическими типами (радикалами) в особенном, идеалистическом мироощущении (чувство первичности Ауха по отношению к материальному, телесному), из которого, в свою очередь, произрастает особое чувство порядка-гармонии, которое, как известно, составляет суть конфуциан- 
ства и конфуцианской культуры. Одновременно это чувство выступает основой того социального и хозяйственного порядка, который утвердился на протяжении последних десятилетий в странах этого региона. Несомненно, данная характерологическая особенность роднит людей этих обществ с людьми общесть Запада, хотя аутистичность народов Восточной Азии характеризуется некоторой ювенильностью, что выражается в доминировании не рационального, а чувственно-образного начала в менталитете этих стран (Просеков, 2015). Напротив, если говорить о России, то Аля нее характерна слабая выраженность аутистического характерологического радикала, и преобладание материалистического мироошущения, с выраженной дефензивностью (природной характерологической оборонительностью, в противоположность агрессивности - наступательности). Что со всей отчетливостью проявляется уже в нашем «основном», свойственном большим массам людей, простонародном характере (Бурно, 2016b: Электронный ресурс). В целом же по сравнению и с людьми Запада, и с народами конфуцианского региона россияне отличаются значительно менее выраженной рациональностью, что, на наш взгляд, объясняется не только «крестьянским» менталитетом, но и уже упомянутой слабостью аутистического радикала в национальном характере. Это, в свою очередь, влечет и такую особенность, как слабое представление об общественном благе, которое оборачивается неготовностью масс людей самоотверженно трудиться ради реализации общественных целей. В итоге типично российский социум - это анархический сочиум, место скопления «частных воль», - от простого человека до влиятельного чиновника-бюрократа, - воль, которые направлены на утверждение не общественного и государственного интереса, но исключительно интереса своего частного, в ущерб общегосударственному. Из этого также становится понятным и стремление полагаться исключительно на «своих» в условиях такого «хаотичного» социума, а также коррупция, разъедающая государственный организм сверху донизу, и в значительной мере - особая русская практичность, которая, как показывает финская журналистка, хорошо знающая Россию, есть практичность, не предусматривающая реализачию долгосрочных иелей, поскольку ничего не гарантировано, и все может обрушиться в любой момент. Как пишет Анна- Аена Ааурен, «это я могу объяснить себе только тем, что русские веками жили в обществе, где ни в чем нельзя быть уверенным и где резкие повороты есть часть повседневной жизни. Зачем основательно ремонтировать дом, если тебя в любой момент могут выкинуть из него? Зачем договариваться о встрече за целые сутки, если я завтра могу умереть? Русский фатализм делает жизнь гораздо более гибкой и оставляет больше пространства для маневров. В общем и целом это практично: поскольку случиться может что угодно, не стоит ничего планировать заранее» (Ааурен, 2012: 163). С этой же чертой национального характера, возможно, связана и русская «передельность», поскольку делить - заведомо более легкое и простое занятие, нежели производство нового, - и не потому ли осуществление передела - перманентное состояние российского социума? (Пивоваров, 2006: 50-63).

\section{ЗАКАЮЧЕНИЕ}

Таким образом, мы рассмотрели современный российский капитализм с трех разных, но взаимосвязанных точек зрения - социологической, политико-экономической и антропологической. С социологической точки зрения это - клановый капитализм, в котором отношения между хозяйствующими субъектами определяются не 
конкуренцией, а неформальными отношениями. С политико-экономической точки зрения ключевым феноменом, определяющим «лицо» российского капитализма, является власть-собственность. Именно наличие системы власти-собственности во многом предопределяет клановый характер российского капитализма. И, наконец, с антропологической точки зрения важна слабая выраженность в России замкнуто-углубленного (аутистического) характерологического радикала (типа характера), что существенно затрудняет формирование правового государства и открывает широкий простор для злоупотреблений. Антиподом российскому капитализму выступает капитализм в странах Восточной и Юго-Восточной Азии (Китай и «тигры»), сумевших, во многом благодаря своему менталитету и особенностям национального характера, воплотить образцы успешного социально-экономического развития.

\section{СПИСОК АИТЕРАТУРЫ}

Антипин, С. А. (2014) Влияние национальной культуры на развитие экономики. Феномен экономического успеха Китая // Аиалог культур и партнерство цивилизаций: XIV Международные Аихачевские научные чтения. 15-20 мая 2014 г. СПб. : СПбГУП. 592 с. С. 476-478.

Бурно, М. Е. (2016а) Замкнуто-углубленные характеры (шизоидные психопаты) [Электронный ресурс]// Психопатология и аддиктивная медицина. Т. 2. № 2. С. 19-35. URL: http://pamrus.ruspsy.net/article.php?post=629 (дата обращения: 05.10.2016).

Бурно, М. Е. (2016b) Смешанные (мозаичные) характеры простонародных людей (простонародные характеры) [Электронный ресурс]// Естественно-научные исследования творческого процесса. URL: http://characterology.ru/characterology/characters/the-common-people-character/ (дата обращения: 05.10.2016).

Бурно, М. Е. (2008) О характерах людей (психотерапевтическая книга). Изд. 3-е, испр. и доп. М. : Академический Проект ; Фонд «Мир». 639 с.

Волков, П. В. (2013) Психологический лечебник: Разнообразие человеческих миров. Руководство по профилактике душевных расстройств. М. : Этерна. 640 с.

Гаман-Голутвина, О. В. (2010) Авторитаризм развития или авторитаризм без развития: судьбы модернизации на постсоветском пространстве // Вестник МГИМО Университета. №4. С. 77-84.

Глебова, И. И. (2006) Как Россия справилась с демократией: Заметки о русской политической культуре, власти, обществе. М. : РОССПЭН. 142, [1] с.

Аенисов, А. И. (2011) Китайский путь: уроки для России [Электронный ресурс] // Вестник McKinsey. Теория и практика управления. № 22. URL: http://vestnikmckinsey.ru/goverment/kitajskij-put-uroki-dlya-rossii (дата обращения: 05.10.2016).

Азарасов, Р. С. (2012) Инсайдерская рента определяет российский капитализм: ответ Симону Пирани [Электронный ресурс]. URL: http://dzarasov.ru/razryv-ili-preemstvennost (дата обращения: 05.10.2016).

Илларионов, А. (2007) Силовая модель - это не капитализм [Электронный ресурс]// Институт экономического анализа. URL: http://www.iea.ru/siloviki_model.php?id=18 (дата обращения: 05.10.2016).

Кагарлицкий, Б. Ю. (2009) Периферийная империя: циклы русской истории. М. : Алгоритм; Эксмо. 576 с.

Косалс, А. Я. (2011) Аеловой климат в клановой экономической системе // История новой России. Очерки, интервью: в 3 т. / под общ. ред. П. С. Филиппова. СПб. : Норма. Т. 1. 688 с. C. 405-448.

Красильщиков, В. А. (2003) Азиатские «тигры» и Россия: страшен ли бюрократический капитализм? // Мир России. № 4. С. 3-43.

Аамажаа, Ч. К. (2010) Клановость в политике регионов России: Тувинские правители. М. : Книжный дом «Аиброком». 208 с. 
Ааньков, А. (2010) Модернизация в Восточной Азии, 1945-2010 [Электронный ресурс] // Полит.Py. URL: http://polit.ru/article/2010/03/11/lankov/ (дата обращения: 05.10.2016).

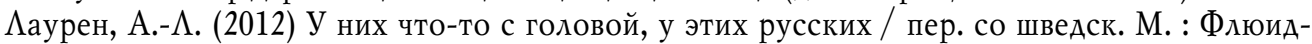
ФриФлай ; Флюид-Урал. 189, [2] с.

Нуреев, Р. М., Аатов, Ю. В. (2011) Когда и почему разошлись пути России и Западной Европы? (Подход с позиции институциональной экономической истории) // Мир России: социология, этнология. № 4. С. 24-67.

Пивоваров, Ю. С. (2006) Русская политика в ее историческом и культурном отношениях. М. : РОССПЭН. 166 с.

Просеков, С.А. (2015) Менталитет китайцев и реформы Аэн Сяопина // Философские науки. № 1. С. 86-98.

Розмаинский, И. В., Аожникова, А. В. (2014) Размышления о капитализме, инновациях и динамизме в постоветской России // Journal of Institutional Studies (Журнал институциональных исследований). Т. 6. № 4. С. 32-50.

Соколов, А. А. (2013) Инвестиционное поведение государственных корпораций в условиях инсайдерского контроля // Вестник Университета. Т. 6. № 5. С. 25-33.

Федотова В. Г., Федотова Н. Н. (2002) Россия в глобальном и внутреннем мире // Модернизация и глобализация: образы России в XXI веке (2002) / отв. ред. В. Г. Федотова. М. : ИФРАН. 208 с. С. 4-30.

Явлинский Г. А. (2007) Российская экономическая система. Настоящее и будущее. М. : ИзА-во «Медиум». 416 с.

Аата поступления: 10.10 .2016 г.

CONTEMPORARY RUSSIAN CAPITALISM:

SOCIOLOGICAL, POLITICAL-ECONOMIC AND ANTHROPOLOGICAL ASPECTS

G. YU. KANARSH

(INSTITUTE OF PHILOSOPHY, RUSSIAN ACADEMY OF SCIENCES)

The article presents a comprehensive socio-philosophical analysis of the phenomenon of contemporary capitalism in Russia. We suggest that it should be studied from three interrelated points of view - respectively, sociological, political-economic and anthropological. A special focus is made on the links between Russian capitalism and the challenges of globalization.

As we show in the article, from a sociological point of view the Russian version of capitalism can be described as a clan system, where relationships are founded on personal (informal) relations rather than on competition (unlike the "regular" capitalist system). In its turn, the clan system is a form of carrying on economic activity. The rise of the cronyist clans is due to the phenomenon of power-property and its manifestations in modern Russia. At the same time, the current absolute domination of the state bureaucracy and the weakness of the legal principles in contemporary Russian society can be explained from either a historicist or a characterological standpoint. We suggest that the key reason for this lies is the weakness of schizoid (autistic) characterological radical (type of character) in the national character of Russian. On the contrary, the peoples of East and Southeast Asia, who have been demonstrating a truly phenomenal success of capitalist development since about the 1960s, are known for a marked presence of this radical in their national character. The ensuing pragmatism has permeated all the elements of the Asian "economic miracle", from the strict adherence to the rules of social and economic life to painstaking routine work.

Keywords: society in Russia; capitalism; cronyism; power-property; national mentality; national character; newly industrialized countries; "Asian miracle"; modernization

\section{REFERENCES}

Antipin, S. A. (2014) Vliianie natsional'noi kul'tury na razvitie ekonomiki. Fenomen ekonomicheskogo uspekha Kitaia. In: Dialog kul'tur i partnerstvo tsivilizatsii: XIV Mezbdunarodnye Likba- 
chevskie nauchnye chteniia. 15-20 maia 2014 g. Saint-Petersburg, Saint-Petersburg Humanitarian University of Trade Unions. P. 476-478. (In Russ.)

Burno, M. E. (2016a) Zamknuto-uglublennye kharaktery (shizoidnye psikhopaty). Psikbopatologiia $i$ addiktivnaia meditsina, vol. 2, no. 2, pp. 19-35 [online] Available at: http://pam-rus.ruspsy.net/article.php?post $=629$ (access date: 05.10.2016). (In Russ.)

Burno, M. E. (2016b) Smeshannye (mozaichnye) kharaktery prostonarodnykh liudei (prostonarodnye kharaktery). In: Estestvenno-nauchnye issledovaniia tvorcheskogo protsessa [online] Available at: http://characterology.ru/characterology/characters/the-common-people-character/ (access date: 05.10.2016). (In Russ.)

Burno, M. E. (2008) O kharakterakb liudei (psikboterapevticheskaia kniga). 3rd edition, revised and enlarged. Moscow, Akademicheskii Proekt; Fond «Mir». 639 p.

Volkov, P. V. (2013) Psikbologicheskii lechebnik: Raznoobrazie chelovecheskikb mirov. Rukovodstvo po profilaktike dushevnykh rasstroistv. Moscow, Eterna. 640 p. (In Russ.)

Gaman-Golutvina, O. V. (2010) Avtoritarizm razvitiia ili avtoritarizm bez razvitiia: sud'by modernizatsii na postsovetskom prostranstve. Vestnik MGIMO-Universiteta, no. 4, pp. 77-84. (In Russ.)

Glebova, I. I. (2006) Kak Rossiia spravilas's demokratiei: Zametki o russkoi politicbeskoi kul' ture, vlasti, obsbchestve. Moscow, ROSSPEN. 142, [1] p. (In Russ.)

Denisov, A. I. (2011) Kitaiskii put': uroki dlia Rossii. Vestnik McKinsey, no. 22. [online] Available at: http://vestnikmckinsey.ru/goverment/kitajskij-put-uroki-dlya-rossii (access date: 05.10.2016). (In Russ.)

Dzarasov, R. S. (2012) Insaiderskaia renta opredeliaet rossiiskii kapitalizm: otvet Simonu Pirani. In: Dzarasov Ruslan [online] Available at: http://dzarasov.ru/razryv-ili-preemstvennost (access date: 05.10.2016). (In Russ.)

Illarionov, A. (2007) Silovaia model' - eto ne kapitalizm. In: Institut ekonomicheskogo analiza [online] Available at: http://www.iea.ru/siloviki_model.php?id=18 (access date: 05.10.2016). (In Russ.)

Kagarlitskii, B. Yu. (2009) Periferiinaia imperiia: tsikly russkoi istorii. Moscow, Algoritm; Eksmo. 576 p. [online] Available at: http://e-libra.ru/read/237011-periferijnaya-imperiya-ciklyrusskoj-istorii.html (access date: 05.10.2016). (In Russ.)

Kosals, L. Ya. (2011) Delovoi klimat v klanovoi ekonomicheskoi sisteme. In: Istoriia novoi Rossii. Ocherki, interv'iu: in 2 vols., ed. by P. S. Filippov, vol. 1. Saint-Petersburg, Norma. 688 p. pp. 405-448. (In Russ.)

Krasil'shchikov, V. A. (2003) Aziatskie «tigry» i Rossiia: strashen li biurokraticheskii kapitalizm? Mir Rossii, no. 4, pp. 3-43. (In Russ.)

Lamazhaa, Ch. K. (2010) Klanovost'v politike regionov Rossii: Tuvinskie praviteli. Moscow, Librokom. 208 p.

Lan'kov, A. (2010) Modernizatsiia v Vostochnoi Azii, 1945-2010 [online] Available at: http:// polit.ru/article/2010/03/11/lankov/ (access date: 05.10.2016). (In Russ.)

Lauren, A.-L. (2012) U nikh chto-to s golovoi, u etikh russkikh. Moscow, ID FluidFriFlai; FliuidUral. 189 p. (In Russ.)

Nureev, R. M., Latov, Yu. V. (2011) Kogda i pochemu razoshlis' puti Rossii i Zapadnoi Evropy? (Podkhod s pozitsii institutsional'noi ekonomicheskoi istorii). Mir Rossii: sotsiologiia, etnologiia, no. 4, pp. 24-67. (In Russ.)

Pivovarov, Yu. S. (2006) Russkaia politika $v$ ee istoricheskom $i$ kul'turnom otnosheniiakh. Moscow, ROSSPEN. 166 p. (In Russ.)

Prosekov, S. A. (2015) Mentalitet kitaitsev i reformy Den Siaopina. Filosofskie nauki, no. 1, pp. 86-98. (In Russ.)

Rozmainskii, I. V., Lozhnikova, A. V. (2014) Razmyshleniia o kapitalizme, innovatsiiakh i dinamizme v postovetskoi Rossii. Journal of Institutional Studies (Zhurnal institutsional'nykb issledovanii), vol. 6, no. 4, pp. 32-50. (In Russ.) 
Sokolov, A. A. (2013) Investitsionnoe povedenie gosudarstvennykh korporatsii v usloviiakh insaiderskogo kontrolia. Vestnik Universiteta, no. 6, pp. 82-90. (In Russ.)

Fedotova V. G., Fedotova N. N. (2002) Rossiia v global'nom i vnutrennem mire. In: Modernizatsiia $i$ globalizatsiia: obrazy Rossii v XXI veke / ed. by V. Fedotova. Moscow, Institute of Philosophy RAS. 208 p. P. 4-30. (In Russ.)

Yavlinskii G. A. Rossiiskaia ekonomicheskaia sistema. Nastoiashchee $i$ budushchee. Moscow, Medium, 2007. 416 p. (In Russ.)

Submission date: 10.10.2016.

Канарш Григорий Юрьевич - кандидат политических наук, старший научный сотрудник сектора социальной философии Института философии РАН. Адрес: 109240, Россия, г. Москва, ул. Гончарная, д. 12, стр. 1. Тел.: +7 (495) 697-98-93. Эл. адрес: grigkanarsh@yandex.ru

Kanarsh Grigory Yurievich, Candidate of Political Sciences, Senior Research Fellow, Institute of Philosophy, Russian Academy of Sciences. Postal address: 12 Bldg.1 Goncharnaya St. 109240 Moscow, Russian Federation. Tel.: +7 (495) 697-98-93.E-mail: grigkanarsh@yandex.ru 